\title{
Utilization of Multimedia-Based Learning Materials on Civic Education Courses in Shaping the Character of College Students
}

\author{
Kurnisar Kurnisar, Sri Artati Waluyati, Husnul Fatihah, Edwin Nurdiansyah* \\ FKIP \\ Universitas Sriwijaya \\ Palembang, Indonesia \\ edwin@unsri.ac.id
}

\begin{abstract}
Civic education is one of the Subjects which are compulsory in the curriculum of higher education in Indonesia, it shows that civic education has an important role in the Indonesia human development character. The success of civic education will be realized if citizens have identity soulless Pancasila, able to appreciate diversity, realizing rights and responsibilities as citizens, as well as being able to play an active role in every area of academic life on campus including produce solutions of various problems of the country. Thus, learning education courses Citizenship must be packed in such a way in order to be able to achieve educational goals that have been set. One strategy to teach civic education Courses be more interesting is to take advantage of Multimedia-based learning materials. The characteristics of learners in a digital era makes the world of education needs to be adapted so that the development of information and communication technology needs to be applied in the process of learning Citizenship education courses.
\end{abstract}

Keywords-character; civic education; utilization of multimedia

\section{INTRODUCTION}

The course of civic education is one of compulsory subjects in higher education units as mandated in Law no. 12 Year 2012. In the civic education curriculum included in the group Personality Development Courses with a weight of 2 credits. PKn (civic education) organizes the substance of the study as follows:

- The nature of civic education in the development of an undergraduate or professional proficiency.

- National identity,

- National integration

- Values and norms,

- Harmony of obligations and rights of state and citizens,

- Indonesian Democracy,

- Law enforcement.

- Wawasan Nusantara

- National Resilience [1]
If concluded, Civics involves learning about moral, political, and legal values in the state structure with Pancasila as its basic foundation. Meanwhile, in essence Civics is the result of synthesis between civic education, democracy education, and citizenship based on Pancasila philosophy and contains Indonesian national identity as well as material content about state defenses' [2]. Based on the essence of PKN Indonesia based on Pancasila, formulates that: "Civics in Indonesia is an education of nationality and citizenship in the face of the existence of the Unitary State of the Republic of Indonesia (NKRI), democracy, human rights and ideals to realize Indonesian civil society by using Pancasila philosophy as its analysis blade" [3].

Civic education aims to form learners into human beings who have a sense of nationality and love of the homeland has a very strategic position in the formation and development of the nation. Therefore, one of the conditions for the realization of a democratic citizen is to obtain civic education, through which citizens will understand about their rights and obligations in the life of the nation and state.

The legal basis for the implementation of Civics is regulated in Law Number 20 Year 2003 on National Education System (Sisdiknas) and based on the Decree of the Minister of National Education Number 232 / U / 2000 on Guidelines for the Preparation of Higher Education Curriculum and Assessment of Student Learning Results and Number 045 / U / 2002 on the Higher Education Core Curriculum it has been established that Religious Education, Language Education, and Civics are the Personality Development courses, which must be provided in the curriculum of each study program / study field.

The basis of the implementation of Civics education also explains that the Citizenship Education Course has a very large share in the formation of student characters. The character in particular is the character, character, morality, or personality formed by the internalization of virtues that are believed and used as the basis for the worldview, thinking, attitude, and action. Virtue consists of a number of values, morals, and norms, such as honest, courageous, trustworthy, and respectful to others. The interaction of someone with others fosters the character of society and the character of the nation. 
So, the Citizenship Education Course should be able to:

- developing the potential of soul / conscience / affective of students as human beings and citizens who have cultural values and character of the nation;

- developing the habits and behavior of students who are commendable and in line with the universal values and cultural traditions of religious nations;

- instilling the soul of leadership and responsibility of the students as the next generation of the nation;

- developing the ability of students to become human self-reliant, creative, insightful nationality; and

- develop the school life environment as a safe, honest, full of creativity and friendship, and with a high sense of dignity.

Values in the Character Education that appear is:

- Religion: Indonesian society is a religious society. Therefore, the lives of individuals, societies, and nations are always based on the teachings of religion and belief.

- Pancasila: the unitary state of the Republic of Indonesia is upheld on the principles of national and state life called Pancasila. Pancasila is present in the Preamble to the 1945 Constitution and further elaborated in the articles contained in the 1945 Constitution.

- Culture: as a truth that no human being lives in a society that is not based on recognized cultural values. Cultural values that serve as the basis in giving meaning to a concept and meaning in communication among members of that society.

- National Education Objectives: as a quality formula that every Indonesian citizen must have, developed by various educational units at various levels and pathways. The purpose of national education contains various humanitarian values that must be owned by Indonesian citizens. [4]

Based on the four sources of value, it generates a number of values for cultural education and character of the nation, namely:

- Religious: a submissive attitude and behavior in carrying out religious teachings that are adhered to, tolerant of the implementation of other religious services, and living in harmony with the followers of other religions.

- Honest: a behavior based on truth, avoid wrong behavior, and make himself a trustworthy person in words, actions, and work.

- Tolerance: an action and attitude that respects opinions, attitudes and actions of others that are different from their opinions, attitudes, and actions.

- Discipline: an orderly and aptuh action on various provisions and regulations that must be implemented.
- Hard work: an effort shown to always use the time available for a job to the best of it so that the work done is done in time

- Creative: think to produce a new way or product from what has been owned

- Independent: the ability to do the job itself with the ability that has been owned

- Democratic: attitudes and actions that value the rights and obligations of himself and others in the same position

- Curiosity: an attitude and action that always strives to know what it is learning more deeply and extensively in various related aspects.

- The spirit of nationality: a way of thinking, acting, and insight that puts the interests of the nation and state above the interests of self and its group.

- Love of the homeland: an attitude that shows loyalty, caring, and high appreciation to the physical, social, cultural, economic, and political environment of its people.

- Respect for achievement: an attitude and actions that drive itself to produce something useful for society, and recognize and respect the success of others.

- Friendly / communicative: an act that shows the pleasure of talking, getting along, and working with others.

- Peaceful love: an attitude and actions that always make others happy and well received by others, society and nation

- Glad to read: a habit that always provides time to read reading material that gives virtue for itself.

- Social Care: an attitude and action that always wants to provide help to help others and the community in relieving the difficulties they face.

- Caring for the environment: an attitude and actions that always seek to prevent damage to the surrounding natural environment, and develop efforts to repair the already existing natural damage.

Some of these characters can be developed with interesting and varied teaching materials. To compile interesting teaching materials such as with a multimedia base, so the teaching materials can not only be seen but also can be heard even interactive. Teaching Materials are all forms of materials used to assist teachers / instructors in carrying out teaching and learning activities [5]. In line with that understanding, Mudlofir also revealed that teaching materials are all materials used to assist the implementation of learning activities [6]. Thus, it is very important to develop interesting teaching materials. 


\section{DISCUSSION}

This study begins with analyzing the phenomenon of course study, preliminary study conducted by analyzing the phenomenon as well as barriers to character formation in the civic education course. Among them in the formation of the character of students must be able to see a real example of good characters and bad characters, not just listen to lectures from lecturers. Therefore, must be designed in such a way as a learning support tool that is able to make the learning process becomes more meaningful and able to achieve the learning objectives with more leverage.

One of the learning tools that can support the achievement of learning objectives is teaching materials. But the teaching materials will be boring if only textbooks like most are used today, whereas the users of this teaching materials especially students in the digital age are eager for teaching materials that are practical and not boring and easy to access. Regarding the development of teaching materials, Dick and Carey put forward several points to note: (1) taking into account the desired learning motivation, (2) the suitability of the given material, (3) following a correct sequence, (4) (7) available tests in accordance with the material provided, (8) available guidelines for follow-up or general progress of learning, (9) available guidance for learners for the stages of activity performed, and (10) can be remembered and transferred [7].

With regard to it, the teaching materials that will be developed and used should take advantage of technological developments as a base or better known as multimedia. With multimedia teaching materials students will be interested to use it because it is more practical and able to be utilized interactively. Raharjo (in Rusman) reveals research results that show that teaching and learning activities will be effective and easy when assisted by visual means, where $11 \%$ of the learned through the sense of hearing, while $83 \%$ through the sense of sight. It is further stated that we can only remember $20 \%$ of what we hear, but can remember $50 \%$ of what is seen and heard. In an increasingly sophisticated era like today, the use of various multimedia applications is very good to be utilized as teaching materials, for example the use of Camtasia, Edmodo, Moddle and many more. Multimedia applications provide a variety of image options and then can include video and animation into it so that the resulting material can be more interesting and have more variety [8].

One of the multimedia programs that can be used to develop teaching materials is Flash Flip Book. At first flash flip book widely used mass media to create an online version of the print version, but now flash flip book can also be used for the manufacture of teaching materials. Making flashflip bookbased instructional material is done by using software / software that is open source that is Kvisoft Flipbook Marker which is software / software used to make the display of books or other teaching materials into a digital book-shaped electronic flipbook. Display of teaching materials using flip book application can be seen in the following figure,

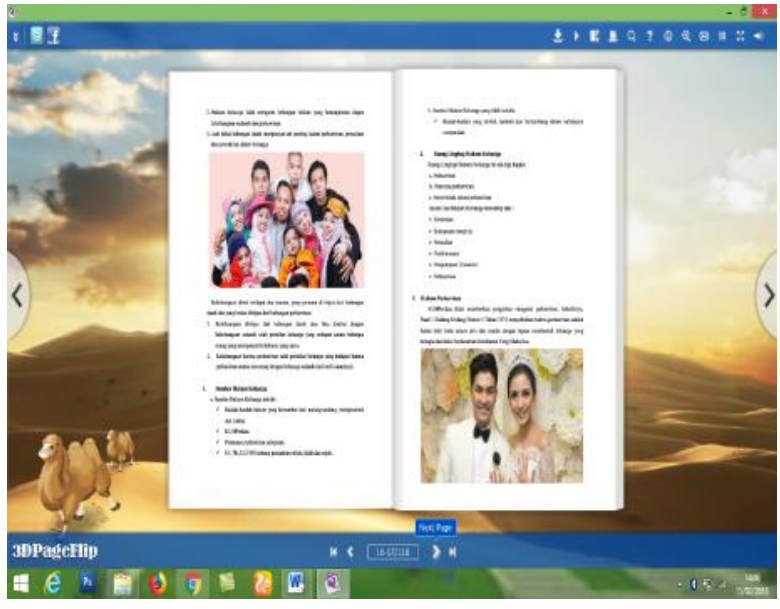

Fig. 1. Display of teaching materials using flip book application 1

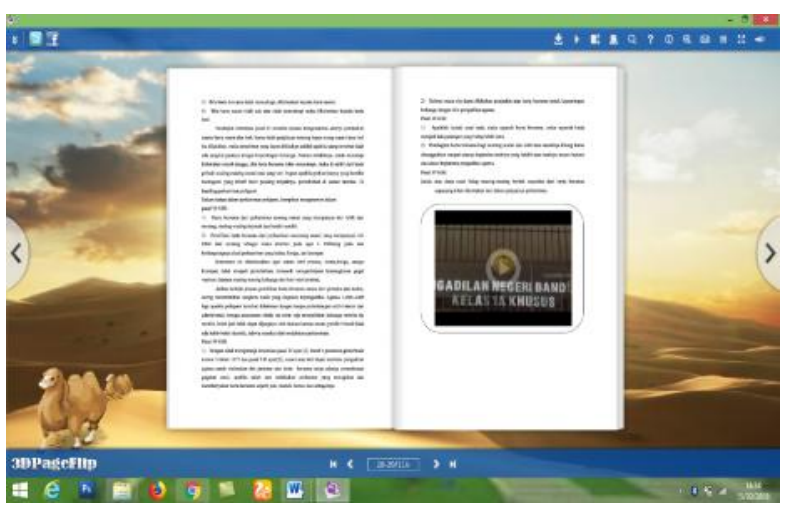

Fig. 2. Display of teaching materials using flip book application 2

In teaching materials developed with flip book applications can include a variety of media both audio, visual and audio visuals so that these teaching materials can provide a direct example in the form of video pieces. According to Rusman multimedia-based learning is a learning activity that utilizes computers to create and combine text, graphics, audio, moving images (video and animation) by combining links and tools that enable the user to navigate, interact, create, and communicate [9]. In line with this understanding, multimedia is also interpreted as a merger of some elements of media consisting of graphics, text, photos, audio, and animation [10]. The use of various multimedia applications is very good to be utilized to modify the teaching materials so that it can be more interesting and attractive.

\section{CONCLUSION}

Based on the description concluded if the formation of student characters is very effective done by using multimediabased teaching materials. Teaching materials that can be seen, heard and can even interact with students. So that students can learn real how good character in accordance with the concept of education character and bad character. But the weakness of multimedia-based teaching materials is not compatible on all devices so that only certain software that can use multimedia applications, so cannot be studied anywhere and anytime. 
For further development of teaching materials should be more practical and able to be more easily used and can be used in all software especially IOS and Android based so it can be more easily used because it can be used in smartphones.

\section{ACKNOWLEDGEMENTS}

On this occasion, the authors present thanks to the Chairman and the LPPM Sriwijaya University, Dean FKIP Sriwijaya University who have facilitated this research, as well as the respondents who gave the best response in the completion this research.

\section{REFERENCES}

[1] Winataputra. U. Materi dan Pembelajaran PKn SD. Jakarta. Universitas Terbuka. 2008.
[2] Kaelan \& Zubaidi. Pendidikan Kewarganegaraan. Yogyakarta. Paradigma. 2007.

[3] Erwin, M. Pendidikan Kewarganegaraan Republik Indonesia. Bandung. Refika Aditama. 2012

[4] Hidayatullah \& Rohmadi. Pendidikan Karakter. Surakarta. Yuma Pustaka. 2010

[5] Madjid, A. Perencanaan Pembelajaran. Bandung: Rosda Karya. 2012.

[6] Mudlofir. Kurikulum dan Pengembangan Bahan Ajar. Yogyakarta: Penerbit Ombak. 2011.

[7] Dick \& Carey. The System Design of Instruction. New York: Longman. 1996.

[8] Rusman. Model-Model Pembelajaran Mengembangkan Profesionalisme Guru. Jakarta: PT Rajagrafindo. 2012.

[9] Rusman. Belajar dan Pembelajran Berbasis Komputer. Bandung: Alfabeta. 2012

[10] Istiyanto. (2013). Pengertian dan Manfaat Pembelajaran (online). Tersedia http//istiyanto.com/pengertian-dan-manfaat-pembelajran/(18 April 2017) 